\title{
Influence of inherited structural domains and their particular strain distributions on the Roer Valley graben evolution from inversion to extension
}

\author{
Jef Deckers $^{1}$, Bernd Rombaut ${ }^{1}$, Koen Van Noten ${ }^{2}$, and Kris Vanneste ${ }^{2}$ \\ ${ }^{1}$ VITO, Flemish Institute for Technological Research, Boeretang 200, 2400 Mol, Belgium \\ ${ }^{2}$ Seismology-Gravimetry, Royal Observatory of Belgium, Ringlaan 3, 1180 Brussels, Belgium \\ Correspondence: Jef Deckers (jef.deckers@ vito.be)
}

Received: 20 February 2020 - Discussion started: 9 March 2020

Revised: 12 August 2020 - Accepted: 6 November 2020 - Published: 9 February 2021

\begin{abstract}
The influence of strain distribution inheritance within fault systems on repeated fault reactivation is far less understood than the process of repeated fault reactivation itself. By evaluating cross sections through a new 3D geological model, we demonstrate contrasts in strain distribution between different fault segments of the same fault system during its reverse reactivation and subsequent normal reactivation.

The study object is the Roer Valley graben (RVG), a middle Mesozoic rift basin in western Europe that is bounded by large border fault systems. These border fault systems were reversely reactivated under Late Cretaceous compression (inversion) and reactivated as normal faults under Cenozoic extension. A careful evaluation of the new geological model of the western RVG border fault system - the Feldbiss fault system (FFS) - reveals the presence of two structural domains in the FFS with distinctly different strain distributions during both Late Cretaceous compression and Cenozoic extension. A southern domain is characterized by narrow $(<3 \mathrm{~km})$ localized faulting, while the northern is characterized by wide ( $>10 \mathrm{~km}$ ) distributed faulting. The total normal and reverse throws in the two domains of the FFS were estimated to be similar during both tectonic phases. This shows that each domain accommodated a similar amount of compressional and extensional deformation but persistently distributed it differently.

The faults in both structural domains of the FFS strike NW-SE, but the change in geometry between them takes place across the oblique WNW-ESE striking Grote Brogel fault. Also in other parts of the Roer Valley graben, WNWESE-striking faults are associated with major geometrical
\end{abstract}

changes (left-stepping patterns) in its border fault system. At the contact between both structural domains, a major NNESSW-striking latest Carboniferous strike-slip fault is present, referred to as the Gruitrode Lineament. Across another latest Carboniferous strike-slip fault zone (Donderslag Lineament) nearby, changes in the geometry of Mesozoic fault populations were also noted. These observations demonstrate that Late Cretaceous and Cenozoic inherited changes in fault geometries as well as strain distributions were likely caused by the presence of pre-existing lineaments in the basement.

\section{Introduction}

Rift basins are typically bounded by large fault systems. These border fault systems are generally segmented along strike. As they represent zones of pre-existing weaknesses, the large border fault systems are prone to reactivation under either extension or compression. The effects of pre-existing segmentation upon extensional or compressional strain distributions in reactivated rift border fault systems have thus far received little attention. One of the ideal areas to study these effects is at the border fault systems of the Roer Valley graben (RVG). These systems developed in the middle Mesozoic and were reversely reactivated under Late Cretaceous contraction and experienced normal reactivation again under Cenozoic extension (Demyttenaere, 1989; Geluk et al., 1994). The RVG border faults are dominantly NWSE-oriented and locally intersected by WNW-ESE-striking faults (Michon et al., 2003; Worum et al., 2005). Some of the 
largest WNW-ESE-striking faults (such as the Grote Brogel, Lövenicher-Kast, and Veldhoven faults) caused major leftstepping patterns in the overall NW-SE graben border geometry during compression as well as during extension. This is evidenced by gravimetric maps of the area (Fig. 1) and in more detail in maps of the middle Mesozoic (Jurassic), Upper Cretaceous and Cenozoic stratigraphic distributions and thicknesses in the area (see Duin et al., 2006; Deckers et al., 2019). This apparent influence of non-collinear (not in line) WNW-ESE-striking faults on the development of the RVG border fault system through time has, however, never been studied in detail. This study aims at a better understanding of the role that inherited segmentation plays in later episodes of compressional and extensional graben border fault reactivation.

For site location, we selected the western border fault system of the RVG (Fig. 1), which in Flanders (northern Belgium) is characterized by long NW-SE faults (such as the Bocholt, Neeroeteren, Reppel, and Rotem faults) and the major WNW-ESE-oriented Grote Brogel fault (GBF). The Quaternary activity of the GBF and its influence on the local hydrology has recently been studied at two investigation sites by means of shallow boreholes, cone penetration tests, electrical resistivity tomography, and geomorphic analysis by Deckers et al. (2018). To analyze the interaction of the GBF with the other faults in the western RVG and its influence on the large-scale graben geometry, we used recently published layer and fault models of the 3D geological model for Flanders (version 3; G3Dv3 model; Deckers et al., 2019) together with the digital elevation model. The G3Dv3 model of the area was created by the integration and interpretation of all available 2D seismic reflection and borehole data (borehole descriptions and wire line logs). It consists, among other things, of stratigraphic layer and thickness maps for over 100 stratigraphic units ranging from the Quaternary at the surface to the lower Paleozoic strata at depths of almost $10 \mathrm{~km}$. These maps illustrate the Late Cretaceous and Cenozoic stratigraphic distributions with respect to the faults. Evaluating these maps allows reconstructing the geometrical changes in the study area through time.

\section{Geological setting and stratigraphy}

\subsection{Paleo- and Mesozoic}

The Brabant Massif, a relatively stable WNW-ESE-trending continental block that consists of folded lower Paleozoic (Cambrian to Silurian) strata, is present throughout the subsurface of northern Belgium (Flanders). In the northeastern part of the Brabant Massif, the lower Paleozoic strata are covered by a thick (on average $>2000 \mathrm{~m}$ ) wedge of upper Paleozoic (Devonian to Carboniferous) strata in an area referred to as the Campine Basin. The Carboniferous of the Campine Basin starts with a carbonate succession (Dinan- tian), transitioning to shales (Namurian), and ending in fluviatile successions of coal-rich claystone and sandstone alternations (Westphalian). The thickness distribution of Dinantian carbonates suggests syn-sedimentary normal fault activity with NW-SE to E-W strikes (Muchez and Langenaeker, 1993). Deformation of Westphalian strata in turn, points towards late Carboniferous block faulting and tilting, partly along strike-slip faults (Bouckaert and Dusar, 1987). During this deformation phase (Saalian phase in Fig. 2), the roughly $\mathrm{N}-\mathrm{S}$-trending Donderslag Lineament and NE-SW-trending Gruitrode Lineament developed as transpressional structures in the southeastern part of the Campine Basin (Bouckaert and Dusar, 1987; Dusar and Langenaeker, 1992; Figs. 3 and 5). The Donderslag and Gruitrode lineaments are expressed as anticlines in the Westphalian strata with maximum amplitudes of about $500 \mathrm{~m}$ (Rombaut et al., 2021). The deformed Westphalian strata were unconformably overlain by latest Permian and Triassic continental to shallow marine successions.

From the latest Triassic onwards (early Cimmerian phase in Fig. 2; Geluk et al., 1994), fault activity was noted along a large number of predominantly NW-SE- and WNW-ESEstriking faults across the area (Worum et al., 2005). This activity resulted in differentiation of the Paleozoic Campine Basin into several major tectonic blocks. The RVG was the strongest subsiding block, flanked by the Campine Block (CB) in the west and the Peel Block in the east. Probably during the latest Jurassic (late Cimmerian phase in Fig. 2), the entire region was uplifted and most of the syn-rift strata were eroded outside and also locally within the RVG (Fig. 3). For the purpose of this study, the Jurassic and older strata will be referred to as the pre-Cretaceous strata.

During subsequent Late Cretaceous (Campanian to middle Maastrichtian) compression, referred to as the SubHercynian phase, the Campine and Peel blocks experienced subsidence with the deposition of generally between 200 and $300 \mathrm{~m}$ of carbonates of the Chalk Group, while the RVG in between them was squeezed upwards or inverted (Geluk et al., 1994; Figs. 2 and 3). Inversion of the RVG took place by reverse movements along its (pre-existing) border faults (Demyttenaere, 1989). Apatite fission track analyses revealed that the amount of Late Cretaceous uplift of the RVG is remarkably similar to the amount of subsidence of its flanks (Luijendijk et al., 2011). Inversion in the area probably took place under a N-S to NNW-SSE direction of maximum horizontal compression (de Jager, 2003) as the result of convergence between Africa and Europe (Kley and Voigt, 2008). A sharp decrease in the convergence rates between Africa and Europe during the latest Maastrichtian (Rosenbaum et al., 2002) ended the Sub-Hercynian phase in the region. This is evidenced by the widespread deposition of the youngest (uppermost Maastrichtian and Danian) sequence of the Chalk Group, which is also present on top of formerly inverted basins (Deckers and Van der Voet, 2018). Our informal definition of the Chalk Group, however, only contains those parts 


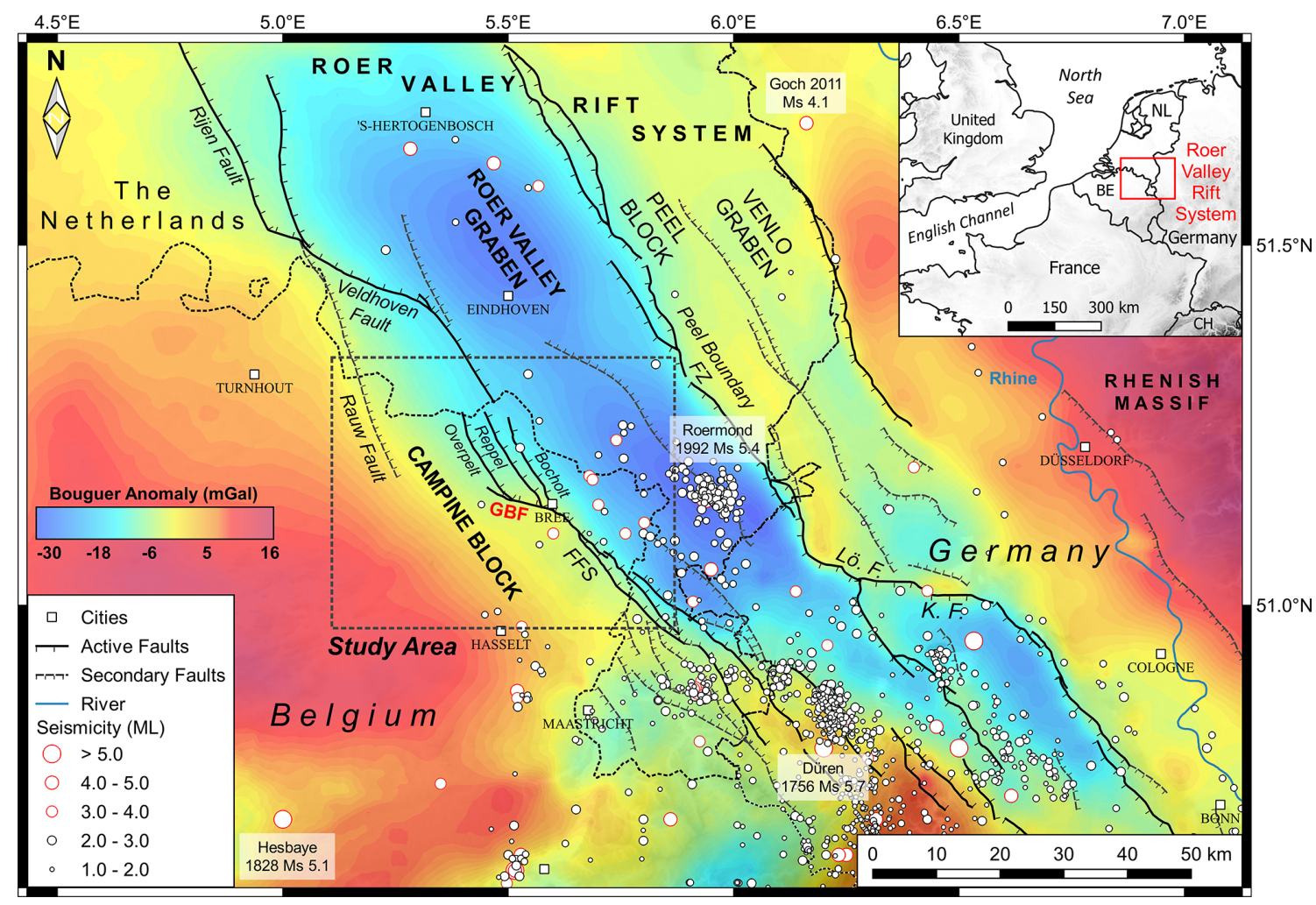

Figure 1. The Roer Valley rift system with its different tectonic blocks, border fault configuration, and seismicity in relation to the Bouguer anomaly. Note the lower Bouguer Anomaly values (Bouguer data gathered by the Royal Observatory of Belgium as described in Everaerts and De Vos, 2012, and Verbeurgt et al., 2019) in the Roer Valley graben related to the thick Cenozoic sequence of uncompacted sediments. The gray dashed square indicates the study area and the location of Figs. 3, 4, and 5. Lö. F.: Lövenich Fault; K. F.: Kast Fault. Surface fault traces modified after Vanneste et al. (2013) and Deckers et al. (2018). Historical and instrumental natural seismicity updated until December 2019 (Seismic catalog of the Royal Observatory of Belgium, 1350-2019).

of the Chalk Group that were deposited during inversion of the RVG, which are missing inside the RVG. The uppermost Maastrichtian and Danian sequences are therefore not included in the informal Chalk Group definition in this study.

\subsection{Cenozoic}

From the early Cenozoic onwards, the study area was situated in the southern part of the North Sea basin and covered by several hundreds of meters of siliciclastics (Fig. 2). Some tectonic phases did occur between the start of the Paleogene and the end of the early Oligocene (Fig. 2), but without major fault activity (see Deckers and Van der Voet, 2018). For the purpose of this study, the latest Maastrichtian to early Oligocene strata are referred to as the pre-rift strata.

Major fault activity resumed in the late Oligocene, when the Roer Valley rift system developed as a northwest-trending branch of the Rhine Graben system (Ziegler, 1988), throughout the southeastern part of the Netherlands, eastern Belgium, and adjacent parts of Germany (Fig. 1). This system currently extends over a distance of roughly $200 \mathrm{~km}$ and has a width of up to $75 \mathrm{~km}$. The faults with the strongest dis- placements divide the central Roer Valley rift system into the Campine Block in the west, the pre-existing Roer Valley graben in the center, and Peel Block in the east. The Roer Valley rift system is currently still active as indicated by the earthquake activity in the region (Fig. 1). Syn-rift sedimentation started in the late Oligocene with the deposition of the Voort Formation (base syn-rift strata in this study; Fig. 2). After the Oligocene, sedimentation gradually coarsened from shallow to marginal marine glauconitic sands (Bolderberg and Diest formations; clinoforms in Fig. 6) until the end of the Miocene, to coarser marginal marine to fluvial sands in the Pliocene (Mol and Kieseloolite formations), and to gravel-bearing fluvial sands in the Quaternary (Meuse Group; Fig. 2). Due to the relatively strong resistance to erosion of the gravel-bearing sands of the Meuse Group, the easternmost part of the Campine Block is currently a relatively high area (often referred to as the Campine Plateau; Fig. 4) delimited to the west by the deposition limit of these coarse sediments and in the east by the major border faults of the RVG (Beerten et al., 2013; Verbeeck et al., 2017), which separate the Campine Plateau from the Reppel, Kaulille, and Bocholt plains (Paulissen, 1997; Fig. 4). 


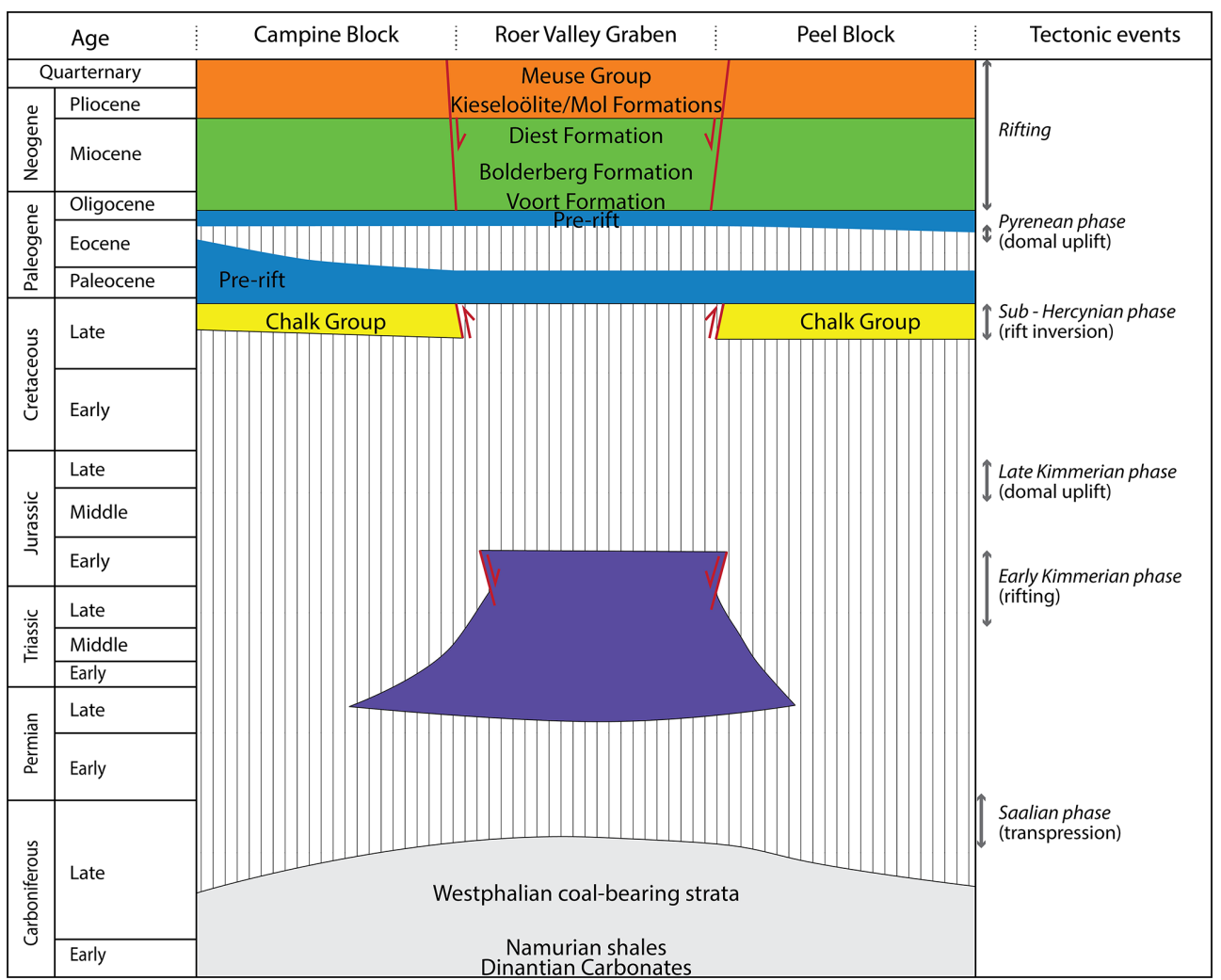

Figure 2. General stratigraphy, ages, and the main tectonic phases within the Campine Block, Roer Valley graben, and Peel Block. Figure modified after Geluk et al. (1994).

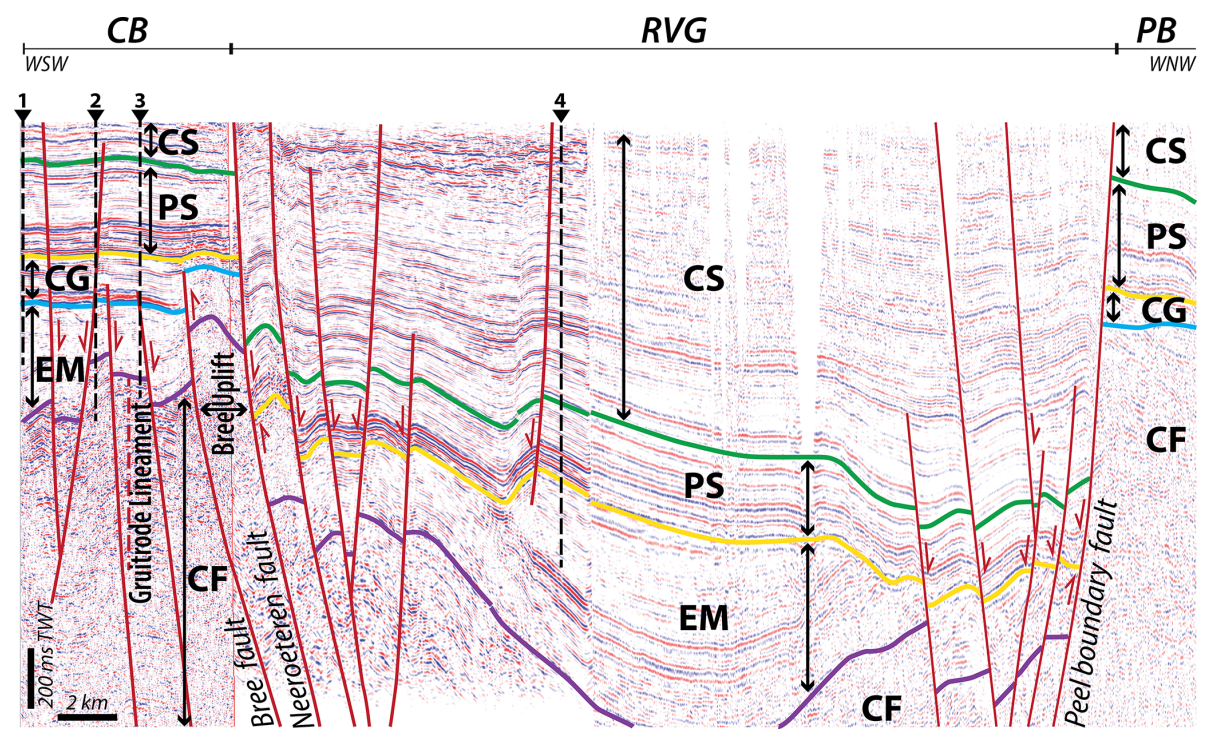

Figure 3. Composite seismic section (constructed from three seismic lines) from the Campine Block (CB) in the west, across the Roer Valley graben (RVG) in the center up to the Peel Block in the east. The location of this section is shown in Fig. 5. Note the presence of thick early to middle Mesozoic strata but absence of the Chalk Group within the RVG. The western part of this section extends across the southern domain of this study and highlights the intersection with the latest Carboniferous Gruitrode Lineament. CF: Carboniferous strata; CG: Chalk Group; CS: Cenozoic syn-rift strata; EM: early and middle Mesozoic strata; GL: axis of the Gruitrode Lineament; PS: pre-rift strata. Numbers represent boreholes at or nearby the seismic lines: 1 - Meeuwen (DOV code: $k b 18 d 48 w-B 173$ ); 2 - Gruitrode (DOV code: $k b 18 d 48 w$-B186); 3 - Bree (DOV code: kb18d48w-B193); 4 - Molenbeersel (DOV code: $k b 18 d 49 w-B 226)$. 


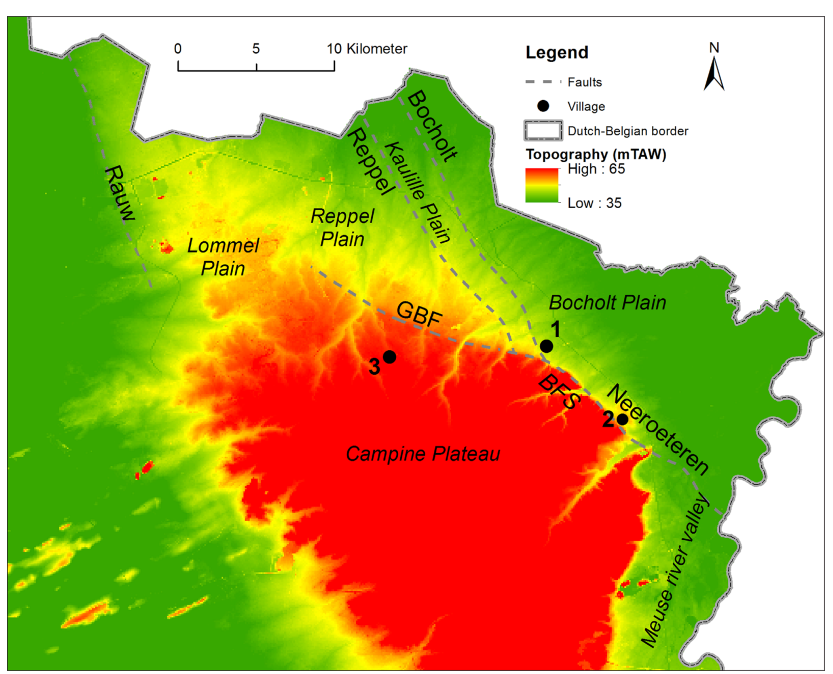

Figure 4. Topography in the study area with indication of the main morphological features and faults of the G3Dv3 model that have a topographic expression. BFS: Bree Fault scarp; GBF: Grote Brogel fault; numbers denote villages: 1 - Bree; 2 - Waterloos; 3 - Peer. DTMV-II model from Agentschap Informatie Vlaanderen (2018).

As a result of continuous rifting since the late Oligocene, the abovementioned stratigraphic units are relatively thick in the RVG (over $1000 \mathrm{~m}$ ) compared to the flanking CB and Peel blocks (generally below 500 m; Demyttenaere, 1989; Geluk, 1990; Fig. 3).

During Miocene to recent rifting, fault distribution in the Roer Valley rift system was characterized by two main trends: the dominant NW-SE (N145-160) trend corresponding to the general orientation of the graben and the secondary WNW-ESE (N110-120) oblique orientation (Michon et al., 2003). These directions were both favorable for fault reactivation under the NE-SW Miocene to recent extensional direction (Michon et al., 2003; Michon and Van Balen, 2005). Along its eastern border, the RVG is separated from the Peel Block by the Peel Boundary fault zone, a NW-SE-oriented, $100 \mathrm{~km}$ long narrow deformation zone composed of the Peel Boundary fault and several secondary faults (Michon and Van Balen, 2005; Fig. 1) with a total vertical throw of 400$800 \mathrm{~m}$ for the base of the Miocene (Geluk et al., 1994). Along its western border, the RVG is separated from the CB by a broad fault bundle, the Feldbiss fault system (FFS), which consists of a number of faults showing a left-stepping pattern (Fig. 1). As a result of this left-stepping pattern, the RVG changes from a near full graben in the center to an asymmetric graben in the north (Michon and Van Balen, 2005; Fig. 1). The FFS is $80 \mathrm{~km}$ long and is mainly composed of the Feldbiss fault, the Geleen (NL) or Neeroeteren (BE) fault, and the Heerlerheide (NL) or Rotem (BE) fault (Michon and Van Balen, 2005; Fig. 4) and shows vertical throws of the base of the Miocene of roughly $400 \mathrm{~m}$ (Demyttenaere and Laga, 1988). The stratigraphic thicknesses indicate that the Peel
Boundary fault system was generally more active than the FFS since the beginning of the Miocene (Michon and Van Balen, 2005; Fig. 3). Consequently, the main Miocene to recent depo-centers developed in the hanging wall of the Peel Boundary fault system.

The study area is centered on the GBF, which is situated in the central portion of the FFS (Fig. 1). The GBF branches off from the major Neeroeteren fault in a WNW-ESE orientation. It has a pronounced geomorphic scarp (up to $4 \mathrm{~m}$ ) which gradually fades away towards the west (Fig. 4). This gradual disappearance coincides with the decrease in fault throw of the Pleistocene Meuse terraces (Deckers et al., 2018).

\section{Dataset and methodology}

\subsection{General dataset}

In the past 2 decades, a large number of (hydro)geological models have been created for the study area (see Langenaeker, 2000; Sels et al., 2001; Beerten et al., 2005; Meyus et al., 2005; Matthijs et al., 2013; Deckers et al., 2019) or parts of it (Deckers et al., 2014; Vernes et al., 2018). For the purpose of this study, we rely on the most recently published 3D subsurface model of Flanders, called the G3Dv3 model (Deckers et al., 2019). This model consists of 3D models of over 100 lithostratigraphic units from the lower Paleozoic (at depths of up to $10 \mathrm{~km}$ ) up to the Quaternary at the surface. The G3Dv3 model also contains 3D surfaces of over 200 faults in the eastern part of Flanders. For the eastern border region between Flanders and the Netherlands, the 3D (hydro)geological models of the Cenozoic stemming from two cross-boundary projects, namely the H3O-Roer Valley graben and H3O-Campine area (Deckers et al., 2014; Vernes et al., 2018), were integrated and stratigraphically further detailed/updated in the G3Dv3 model. Consequently, the G3Dv3 model combines the most recent geological knowledge in Flanders.

The main data sources to create the G3Dv3 model were the following.

- Boreholes: several tens of thousands of borehole descriptions from Flanders are present in the databases of DOV ("Database subsoil Flanders"; https://www.dov. vlaanderen.be/, last access: 2018) and of the Geological Survey of Belgium. Besides the descriptions, these databases often contain one or more interpretations of the lithostratigraphic successions (groups, formations, members) in each borehole. Thousands of these interpretations were selected from these databases as a starting point to create the geological models. After selection, the existing lithostratigraphic interpretations of the boreholes were critically examined and accepted, rejected, or reinterpreted for the different stratigraphic layers. An overview of the boreholes used to map the 
Chalk Group, base syn-rift strata, and base Quaternary and Pliocene strata is shown in Fig. 5.

- Seismic data: the eastern part of Flanders is covered by over 400 lines from numerous seismic campaigns that were performed between 1953 and 2015. This dataset consists of more widely spaced seismic lines from a regional seismic survey acquired between 1953 and 1956 (Campine Basin), complemented by dense networks of more closely spaced lines from local surveys mainly conducted between the 1980s and 2015. In general, the quality of the seismic data improves with time. Besides the age, the targeted depth range of the seismic survey also strongly influences the vertical resolution of the seismic data. Some seismic surveys target deep $(>2 \mathrm{~km}$ ) lower Carboniferous strata, while others target shallow $(<1 \mathrm{~km})$ Cenozoic strata. Consequently, the quality of the resulting image is better for the deep and shallow range. The entire selection of seismic lines was interpreted for horizon and fault mapping. An overview of the interpreted seismic lines to map the Chalk Group and base syn-rift strata is shown in Fig. 5.

- Topographic data: the topography forms the top of the G3Dv3 model. This topography was constructed mainly from the Digital Terrain Model of Flanders (DTMV-II) from Agentschap Informatie Vlaanderen (2018). As a result of their recent activity, several of the large RVG boundary faults are expressed in the topography by relief gradients or scarps (Camelbeeck and Meghraoui, 1996; Paulissen, 1997; Fig. 4). The relief gradient provides a good indication of the location and orientation of the fault traces of these boundary faults at the surface, especially when used in combination with the seismic data.

\subsection{Dataset in the study area}

The dataset used to analyze the study area is limited to a horizontal (area around the GBF) and vertical (depth interval corresponding to Upper Cretaceous and Cenozoic) subset of the G3Dv3 model. Because of this restriction the following data-selection was made.

\subsubsection{Stratigraphic layers}

- The top, base, and thickness of the Upper Cretaceous syn-inversion strata of the Chalk Group were selected, since they illustrate the inversion-related (Late Cretaceous) deformation. The top and base of the Chalk Group were mainly based on seismic interpretations, locally supported by borehole interpretations (for location, see Fig. 5). Boreholes and seismic data show that the Chalk Group is absent within the RVG and up to $300 \mathrm{~m}$ thick in the CB (Fig. 3).
- The bases of the syn-rift (Voort Formation) and Pliocene to Quaternary strata (equivalent Mol and Kieseloolite formations) were selected to illustrate the Cenozoic extension-related deformation. The model of the base syn-rift strata was mainly based on seismic interpretations either from the horizon itself or from a nearby horizon and supported by borehole interpretations (for location, see Fig. 5). The base of the Pliocene to Quaternary strata is generally too shallow to be consistently seismically interpreted and was therefore based on borehole interpretations (for location, see Fig. 5). Due to the shallow location, the number of available boreholes for the Pliocene to Quaternary strata was high compared to those available to map the underlying layers (comparison in Fig. 5).

\subsubsection{Faults}

From the sets of faults in the G3Dv3 models in the study area, we only selected those that show an offset in the Chalk Group and at the base of the syn-rift strata (see Figs. 7 and 9). Due to the relatively large spacing between the boreholes, predominantly seismic data were used for fault mapping. Since all of the considered seismic data are two-dimensional, only fault lines are imaged and their lateral connection into one fault plane remains interpretative. The long faults discussed in this study should therefore not be regarded as single fault planes but rather as fault systems, each of which represents one tectonic feature made up by different fault lines that can represent either linked or isolated fault segments (following Rypens et al., 2004). The interpreted lateral connection of the 2D fault lines into 3D fault systems was predominantly based on the comparison of the variation in vertical displacements between adjacent seismic profiles, locally supported by topographic indications and borehole data. The most reliable fault models are therefore created from areas with low structural complexity, high seismic coverage, large numbers of boreholes, and strong topographic expression of the faults.

Two-dimensional seismic coverage is generally high for the area south of the village of Bree because of the dense networks of different seismic surveys across the RVG border fault system (Fig. 5). The seismic interpretations and lateral connections of the border faults (such as the Bree, Dilsen, Neeroeteren, and Rotem faults) are therefore most reliable in this area. In addition, the major Neeroeteren fault is clearly expressed in the topography as a large $( \pm 30 \mathrm{~m})$ relief gradient, often referred to as the Bree Fault scarp (Camelbeeck and Meghraoui, 1996; Fig. 4).

North of the village of Bree, on the other hand, 2D seismic coverage is very poor with only five long, low- to averagequality seismic lines (either old or only imaging the Cenozoic; Fig. 5). Consequently, interpreting faults and their lateral connections in the RVG border zone on seismic data alone would have a high degree of uncertainty. The southern sections of the Bocholt, GBF, and Reppel faults are, however, 


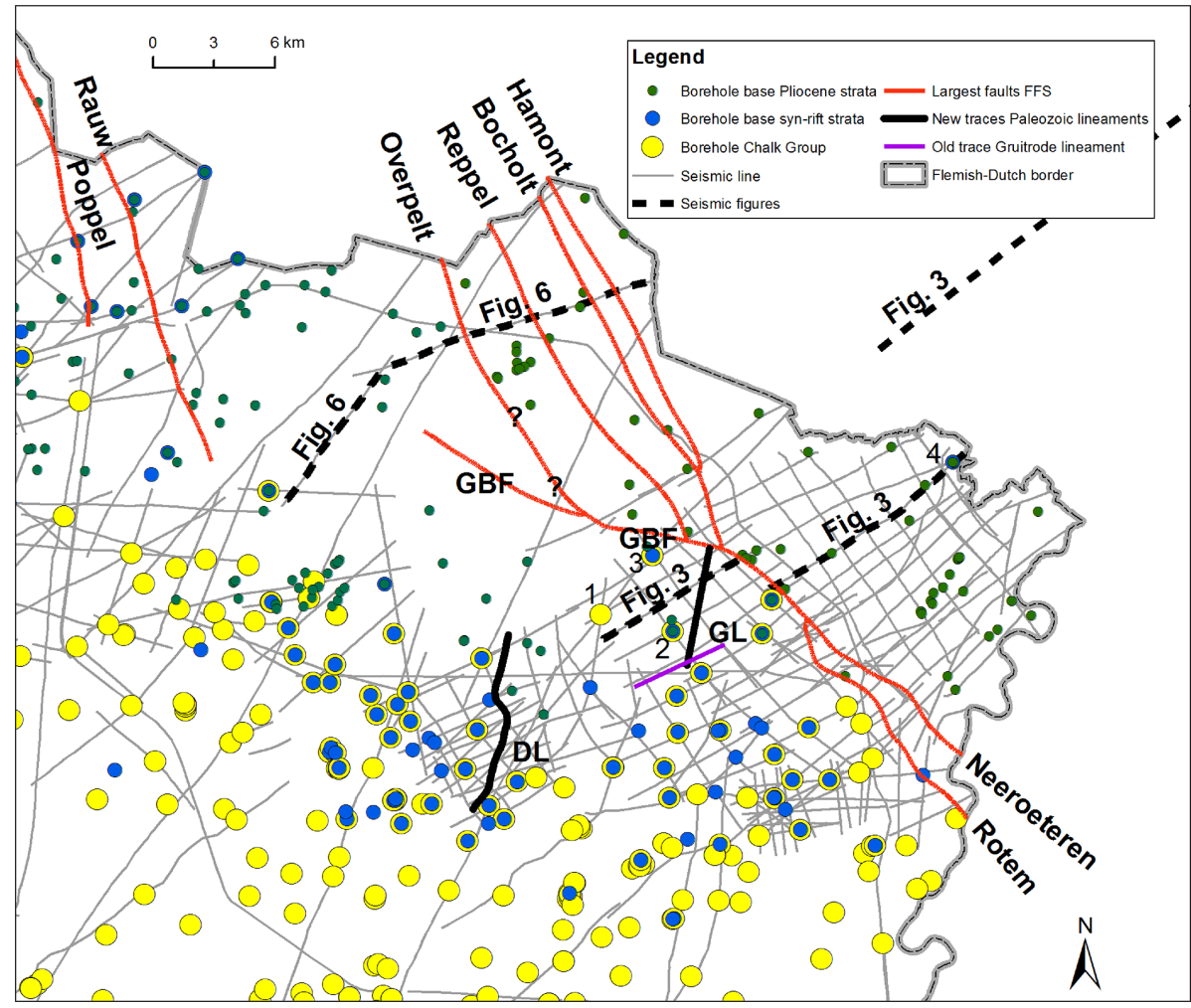

Figure 5. Overview map of the main input data used for the G3Dv3 model of the area, namely seismic lines and borehole selections (for mapping of the bases of the Pliocene, syn-rift strata, and Chalk Group). The composite seismic sections of Figs. 3 and 6 are marked in bold dashed lines. The numbers of the boreholes in Fig. 3 are indicated. The modeled major fault lines of the FFS are marked by red lines, while the modeled axes of the late Paleozoic Donderslag Lineament (DL) and Gruitrode Lineament (GL) are marked by black lines. The old trace of the Gruitrode Lineament by Langenaeker (2000) is shown in purple. Question marks indicate uncertainties in the fault trace.

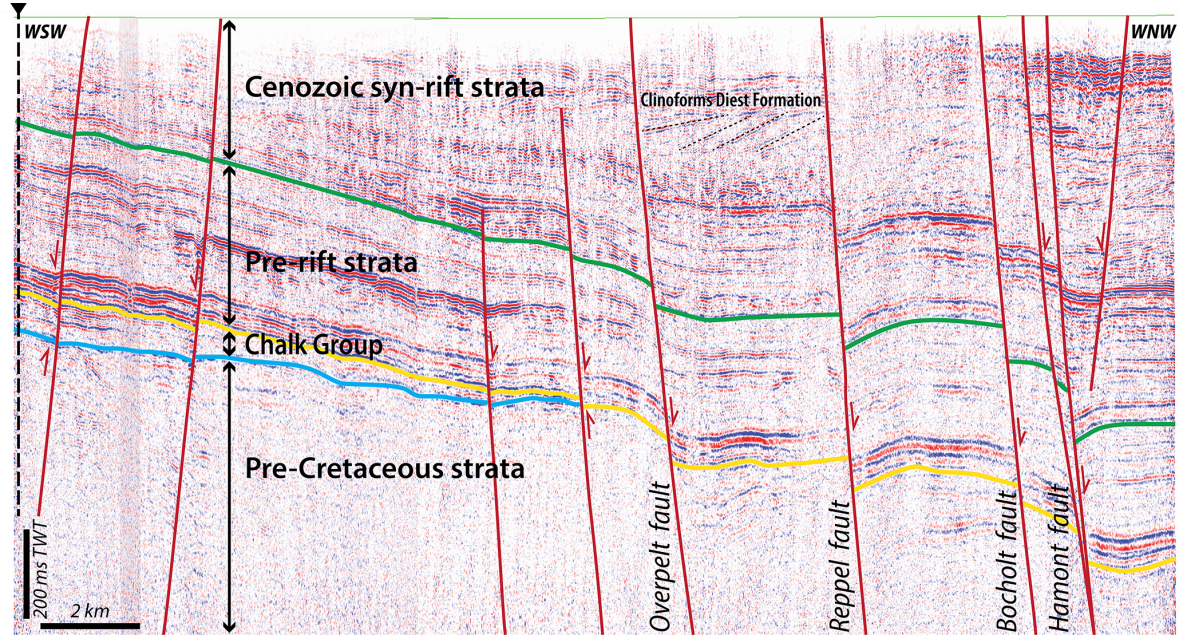

Figure 6. Composite seismic section across the northern structural domain of this study. The location of this section is shown in Fig. 5. Note the gradual decrease in thickness of the Chalk Group and increase in thickness of the Cenozoic syn-rift strata from west to east along the western part of this section. In the eastern part of this section, the Chalk Group is absent and Cenozoic syn-rift strata thicken stepwise across faults. The seismic expressions of some of the westward-prograding clinoforms in the Upper Miocene Diest Formation are indicated. In the westernmost part of this section, the deep borehole Lommel (DOV code: $k b 17 d 47 w-B 262)$ is indicated. 


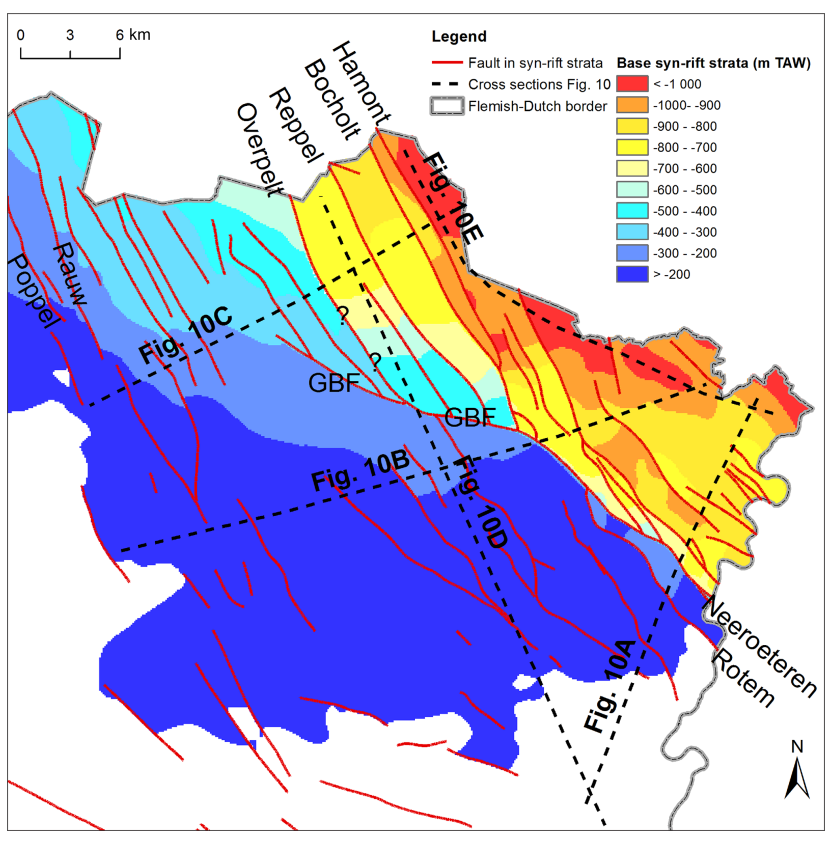

Figure 7. Map showing the depth of the base of the syn-rift strata and the syn-rift faults in the study area from the G3Dv3 model. The locations of the cross sections in Fig. 10 are also indicated. Question marks indicate uncertainties in the fault trace.

clearly expressed by topographic gradients (Fig. 4), which provide support for the seismic fault line connections. At locations where the topographic expression fades, however, the uncertainty increases again:

- In its eastern portion, the GBF is clearly expressed by a topographic gradient of over $10 \mathrm{~m}$ with a clear fault scarp up to $4 \mathrm{~m}$ high near Bree (Deckers et al., 2018; Fig. 4). As its throw decreases in a westerly direction, however, its topographic expression fades, which causes a major uncertainty (of several kilometers) regarding the exact location and extent of the northwestern tip of the GBF.

- In the western portion of the GBF, Demyttenaere and Laga (1988) interpreted an important bend towards the NW-SE Overpelt fault (Fig. 5). The topographic expression is, however, too faint to corroborate this bend in the GBF (Fig. 4). A recently reprocessed seismic line nearby also shows only a minor throw near the location of the supposed bend (question mark in Fig. 5). So although this bend of the GBF towards the Overpelt fault is indicated as a major fault in geological models, its importance remains largely uncertain and is therefore indicated in Figs. 5, 7, and 9 with question marks. Contrary to the bend of the GBF, the presence of the Overpelt fault is supported by several seismic lines (Figs. 5 and 6). The Overpelt fault runs more or less parallel to the Reppel and Bocholt-Hamont faults further east.

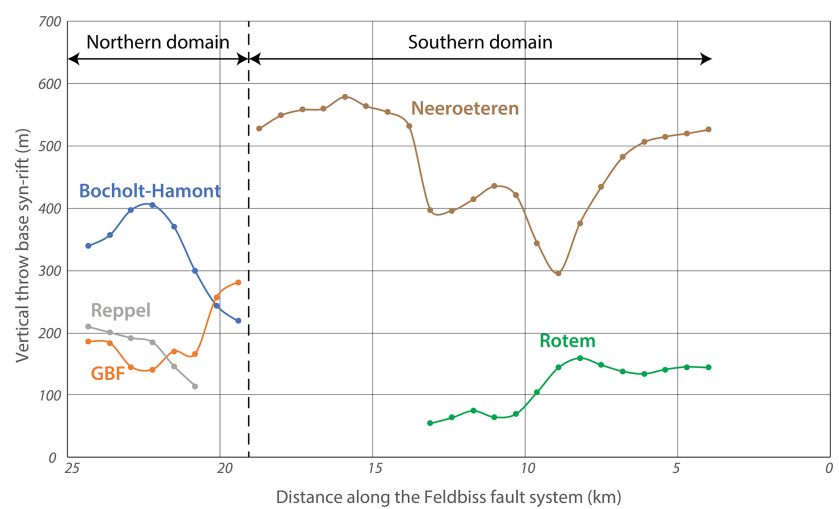

Figure 8. Cenozoic vertical throws along the major faults of the FFS based on the G3Dv3 model. This trace runs from the Belgian-Dutch border in the southeast towards the supposed bending of the GBF into the Overpelt fault in the northwest. Notice the abrupt change in the vertical throw of faults at the boundary between the northern and southern domain.

- Due to the lack of clear topographic expression of faults and due to the diffuse seismic coverage, a large uncertainty remains regarding fault interpretations in the area between the Overpelt fault and the Rauw fault $14 \mathrm{~km}$ further west. West of the Rauw fault, the seismic coverage increases again and the uncertainty regarding fault interpretations and their lateral connection decreases.

\subsubsection{Paleozoic lineaments}

For the G3Dv3 model, the trace of the latest Paleozoic Donderslag Lineament was interpreted on 2D seismic data. In a later modeling of the uppermost Carboniferous strata, the latest Paleozoic Gruitrode Lineament was also interpreted and modeled by means of seismic and borehole data (Rombaut et al., 2021). The expression of the Gruitrode Lineament as an anticline on seismic data is shown in Fig. 3. The traces of the Donderslag and Gruitrode lineaments are shown in Fig. 5.

\subsection{Methodology}

To illustrate the Cenozoic syn-rift geometry in the study area, we show an ArcGIS map view of the depth of the base of the syn-rift strata and the affecting faults from the G3Dv3 model in Fig. 5. An overview of the total vertical throw at the base of the syn-rift strata along some of the major faults of the FFS is shown in Fig. 8.

To illustrate the Late Cretaceous syn-compressional geometry in the study area, we show an ArcGIS map view of the G3Dv3 model of the thickness of the Chalk Group and the major faults that are known to have influenced it in Fig. 9.

Besides the map views, four cross sections (Fig. 10a to e) of the G3Dv3 model were also constructed (by means of iMOD software) to illustrate the Late Cretaceous to recent sediment thicknesses and geometries in the study area. 


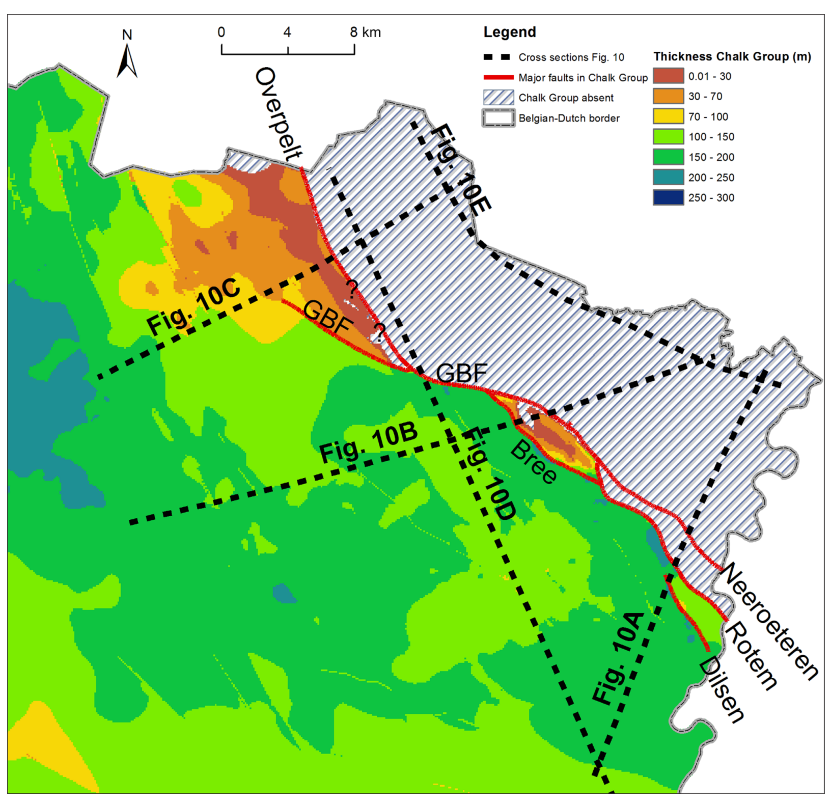

Figure 9. Map showing the thickness of the Chalk Group and major reverse or thrust faults that influenced it in the study area from the G3Dv3 model. The locations of the cross sections in Fig. 10 are indicated. Note that our informal definition of the Chalk Group only contains those parts of the formal Chalk Group that were deposited during inversion of the RVG and are therefore missing in the latter. Younger formations of the formal Chalk Group are grouped in the pre-rift strata for the purpose of this study. Question marks indicate uncertainties in the fault trace.

Three cross sections are SW-NE oriented, perpendicular to the graben trend (Fig. 10a, b, and c), and two others SE-NW oriented, sub-parallel to the graben trend (Fig. 10d and e). On these cross sections, the top and base of the Chalk Group and pre-rift strata are indicated. The syn-rift strata are divided into two parts, namely the late Oligocene and Miocene below and the Pliocene to Quaternary on top.

\section{Results}

\subsection{Structural style of Cenozoic rifting}

The model of the base of the syn-rift strata (base upper Oligocene) illustrates the geometry of Cenozoic rifting. In the RVG, the base of the syn-rift strata is currently situated in the subsurface at depths that generally exceed $-900 \mathrm{~m}$ TAW (Tweede Algemene Waterpassing; Fig. 7). In the CB, the base of the syn-rift strata is located at shallower depths, ranging from $+50 \mathrm{~m}$ TAW in the southwest up to $-400 \mathrm{~m}$ TAW in the northeast (Fig. 10). Towards the easternmost parts of the $\mathrm{CB}$, this trend becomes progressively more disturbed by the presence of faults and tilted blocks in the footwall domain of the FFS (Fig. 7). For individual faults in the CB, the vertical throws at the level of the base of the syn-rift strata do not exceed $80 \mathrm{~m}$.
At the FFS, the base of the syn-rift strata drops by $500 \mathrm{~m}$ from the CB into the RVG (from $-400 \mathrm{~m}$ TAW to $-900 \mathrm{~m}$ TAW; Fig. 7). This jump mainly takes place by - often large - vertical throws along a dense, complex network of normal faults of the FFS and in between those also by an eastward dip of the syn-rift strata (Figs. 3, 6, and 10). Several faults in the FFS have vertical throws at the base of the synrift strata of over $150 \mathrm{~m}$ (Bocholt, GBF, Hamont, Overpelt, Reppel, Rotem), with a maximum of almost $600 \mathrm{~m}$ along the Neeroeteren fault (Fig. 8).

In the RVG itself, vertical fault throws are larger than in the CB but smaller than in the FFS as they generally do not exceed $150 \mathrm{~m}$ (Figs. 3 and 7). Most of the intra-graben faults are dipping in the direction of the nearest graben border fault system (i.e., are antithetic; Fig. 10a and b). The simultaneous activity of the synthetic graben border faults and the antithetic intra-graben faults resulted in a series of long subgrabens in the western flank of the RVG (Fig. 7; Deckers, 2016).

The geometry of the FFS shows strong lateral changes across the study area. Within the FFS, two structural domains and their particular geometry were identified, north and south of the village of Bree (for location, see Fig. 4):

- The southern domain consists of the NW-SE Neeroeteren and Rotem faults (Figs. 7 and 8). The width of this domain is limited to the Neeroeteren fault in the north and from the branching point with the Rotem fault onwards increasing in a southerly direction up to a maximum of $2 \mathrm{~km}$ near the Belgian-Dutch border. Most of the vertical throw of the FFS is taken by the NW-SE-striking Neeroeteren fault, with vertical throws of the base at the syn-rift strata of almost $600 \mathrm{~m}$ (Figs. 7, 8, and 10a and b). The Rotem fault shows a maximum vertical throw of the base of the syn-rift strata of $150 \mathrm{~m}$ (Figs. 7, 8, and 10a). The large vertical throw along the Neeroeteren fault is also expressed by a strong relief gradient denoted as the Bree Fault scarp on top of this fault (topographic offset between 15 and $20 \mathrm{~m}$; Fig. 4). This relief gradient coincides with the boundary between the elevated $(>50 \mathrm{~m}$ TAW) Campine Plateau on top of the CB and the low-lying ( $<40 \mathrm{~m}$ TAW) Bocholt Plain on top of the RVG (see Paulissen, 1997; Fig. 4). The relief gradient of the Bree Fault scarp is evident between Bree and the hamlet of Waterloos but abruptly disappears south of Waterloos due to the WSW-ENE incision by the Quaternary Meuse river from the late Pleistocene onwards (Fig. 4).

- The northern domain starts where the Neeroeteren fault bifurcates into the GBF towards the west and the Bocholt fault towards the north (Figs. 7 and 8). These two faults define the boundaries of the northern domain of the FFS. Since the GBF and Bocholt faults have a WNW-ESE and NW-SE strike, respectively, the northern domain progressively widens in a northerly direc- 
(a)

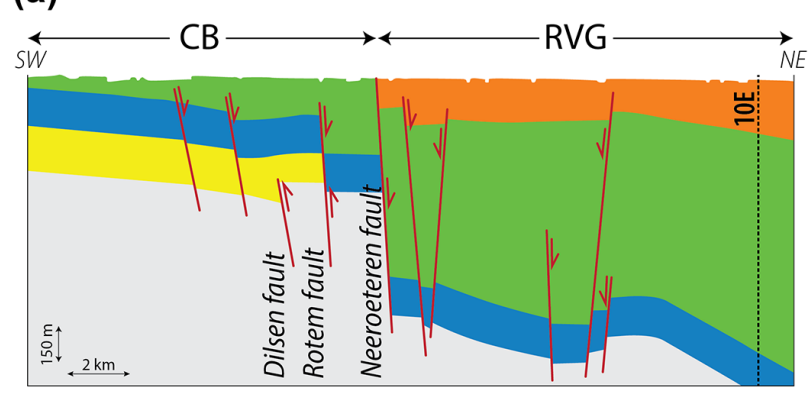

(c)

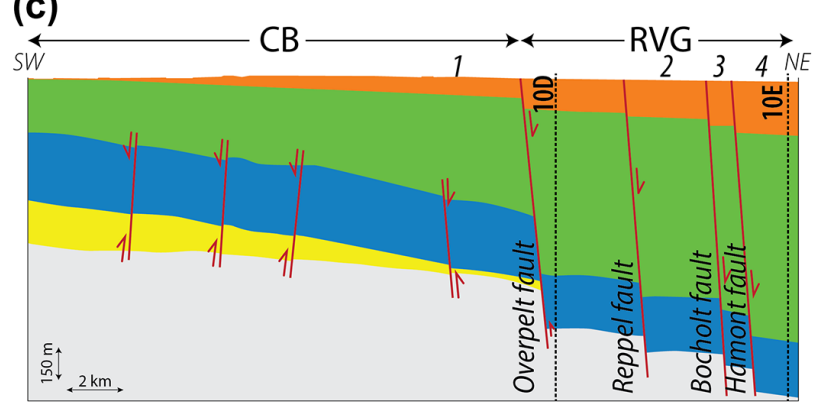

(e)

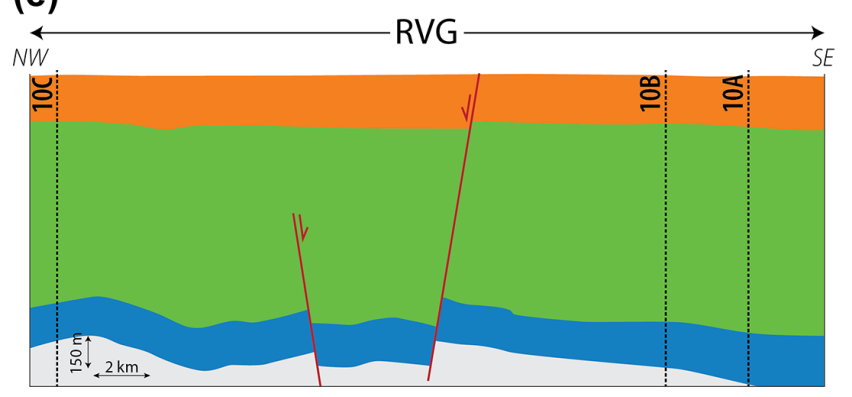

(b)

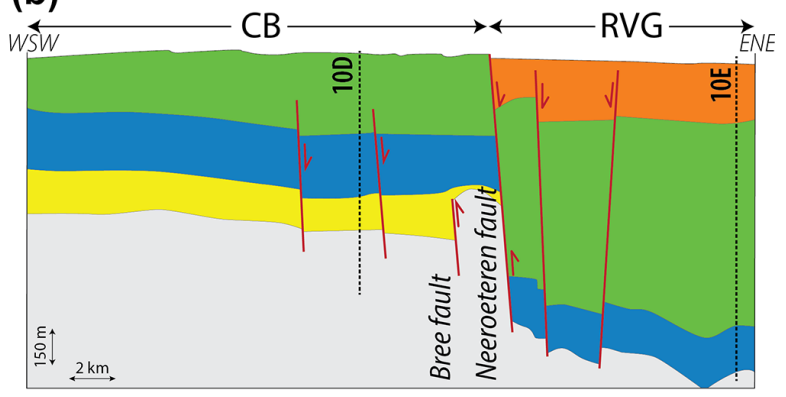

(d)
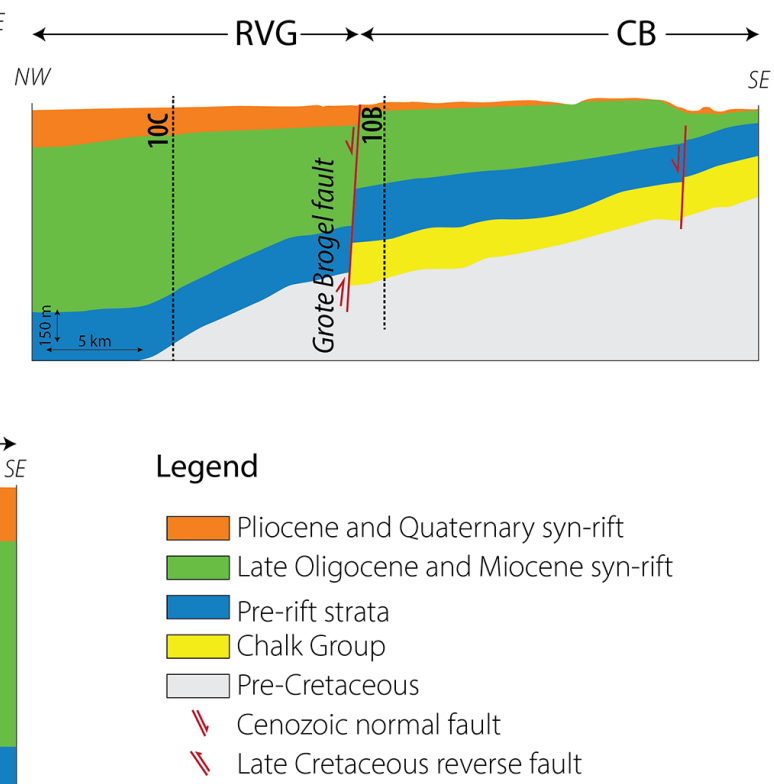

Figure 10. Sections constructed from the G3Dv3 model across (a, b, c) and along (d, e) the FFS. Panels (a) and (b) cross the southern domain of the FFS, while section C crosses the northern domain. Panel (d) runs from the footwall of the southern domain of the FFS (or in the CB) into the northern domain of the FFS. Panel (e) runs across the hanging wall of the FFS or in the RVG. The locations of these sections are indicated in Figs. 7 and 9: 1 - Lommel Plain; 2 - Reppel Plain; 3 - Kaulille Plain; 4 - Bocholt Plain.

tion, reaching a width of up to $13 \mathrm{~km}$ in the central part (Fig. 10c). As it bifurcates, the large vertical throw along the Neeroeteren fault (about $530 \mathrm{~m}$ ) is roughly equally divided over the GBF and Bocholt faults (about 280 and $220 \mathrm{~m}$, respectively; Fig. 8). As a result, while the southern domain delimits a high footwall area in the west from a low hanging wall area in the east, the northern domain shows a more gradual down-faulting in an easterly direction, with relatively small throws across some of its major faults (compare Figs. 3 and 6). The smaller vertical throws along faults in the northern domain are also expressed by absent or only very small relief gradients for most of its faults (excluding the GBF; Fig. 4). As one of the most important faults, the Bocholt fault, for example, shows a vertical topographic offset of a maximum of $4 \mathrm{~m}$ near the town of Bree where the fault is only expressed as a low-angle linear slope without a clear scarp. Consequently, while the Bocholt Plain and Campine Plateau are clearly delimited by the Bree Fault scarp in the southern domain, their transition is much more stepwise along smaller fault scarps in the northern domain (Fig. 4). This stepwise topography has led to the subdivision of the Lommel, Reppel, and Kaulille plains in the northern domain of the FFS and its hanging wall (Paulissen, 1997; Fig. 4). The GBF forms the boundary between the elevated Campine Plateau and the lower Reppel and Kaulille plains and consequently has a large topographic relief in respect of the NW-SE-striking faults in the northern domain. This topographic relief is largest in the east $(15-20 \mathrm{~m})$ where it seems to be in continuation with the Bree Fault scarp associated with the Neeroeteren fault (Deckers et al., 2018). As the total vertical throw along the GBF decreases in a westerly direction, its relief gradient also 
decreases (Fig. 4). This decrease is, however, not gradual. Deckers et al. (2018) noticed an abrupt decrease in the topographic throw at about $2 \mathrm{~km}$ west of the eastern tip of the GBF. These authors related this decrease to the Reppel fault branching off from the GBF, taking over part of the total displacement (Fig. 4). Also at depth, the large vertical throw of the base of the syn-rift strata along the GBF of $270 \mathrm{~m}$ abruptly decreases towards $170 \mathrm{~m}$ across the contact point with the Reppel fault (Fig. 8). This decrease of $100 \mathrm{~m}$ in vertical throw along the GBF is completely accommodated by the vertical throw of $110 \mathrm{~m}$ along the Reppel fault (Fig. 8). West of the bifurcation with the Reppel fault, vertical throw along the GBF decreases further towards $100 \mathrm{~m}$ (Fig. 7). As mentioned above, at the western tip of the GBF, several authors have previously suggested a bend towards the NW-SE Overpelt fault (Demyttenaere and Laga, 1988; Broothaers et al., 2012; Deckers et al., 2014). What is clear from the seismic data is the presence of the NW-SE-striking Overpelt fault further north with vertical throws in the order of $100 \mathrm{~m}$ (Fig. 6). Northwest of the village of Peer, however, the topographic expression of the GBF becomes faint, and there are no further data (borehole nor seismic) to provide indications on its westward continuation (Fig. 4). The decrease in topographic relief in a northwesterly direction coincides with the decrease in vertical throw of the syn-rift strata along the large faults in the northern domain (Fig. 7). Subsidence from the CB towards the RVG is still partly accommodated by small faults but increasingly by a strong northeastward dip of the base of the syn-rift strata (Figs. 7 and 10c).

The cross section of Fig. 10e (or RVG) illustrates that no major changes in the thickness of the syn-rift strata take place from the hanging wall of the southern domain of the FFS towards the hanging wall of the northern domains of the FFS. The map view of Fig. 7 shows that this is also the case in the footwall of the FFS (or CB). This shows that the total throw of the FFS does not strongly change across the boundary between both domains.

\subsection{Structural style of Late Cretaceous inversion}

Under Late Cretaceous compression, the CB and Peel blocks were downthrown, while the RVG in between them was pushed upwards or inverted. Consequently, the Late Cretaceous Chalk Group is absent in the RVG and currently up to $300 \mathrm{~m}$ thick within the $\mathrm{CB}$ (Figs. 3, 6, and 9). Uplift of the RVG was accommodated by reverse movements along its border faults, i.e., the FFS. As the Chalk Group was deposited in the CB during inversion of the RVG, the thickness changes in the Chalk Group across the FFS provide an indication on the (minimum) amount of total reverse throws along the FFS. Since the Chalk Group is about 250 to $300 \mathrm{~m}$ thick in the footwall of the FFS (or CB) and absent in the hanging wall of the FFS (or RVG), the total amount of uplift along the FFS can be estimated at over $300 \mathrm{~m}$ (taking into account later compaction of the chalks). This amount of uplift is consistent with the range $(250$ to $500 \mathrm{~m}$ ) obtained from apatite fission track measurements by Luijendijk et al. (2011) in the nearby borehole Nederweert. Thickness changes in the Chalk Group across individual faults of the FFS can also be used for quantification of the syn-inversion reverse movements along these faults. In the eastern section of the FFS the Chalk Group is, however, absent. Therefore, only reverse movements of the westernmost faults within the FFS can be reconstructed. The thickness maps of the Chalk Group indicate different structural patterns of uplift across the western faults of the FFS. Similar to the Cenozoic (Sect. 4.1), these differences can be separated geographically into a southern and northern domain:

- In the part of the CB south of the town of Bree (for location, see Fig. 4), the thickness of the Chalk Group generally increases in the direction of the RVG to reach a maximum of almost $300 \mathrm{~m}$ in the footwall of the FFS (Fig. 9). From this footwall, the Chalk Group strongly thins across reverse faults. Three major reverse faults were observed, namely the Bree, Rotem, and Dilsen faults. The Chalk Group has a thickness of $250 \mathrm{~m}$ in the footwall of these faults, becoming less than $150 \mathrm{~m}$ thick in the hanging wall of the Dilsen fault (Fig. 10a) and very thin or even absent in the hanging wall of the Bree and Rotem faults (Figs. 3, 10a and b). This shows that vertical reverse throws along faults reached 100 to $250 \mathrm{~m}$ or more. Since the Dilsen fault is present in the footwall and converges (in the Paleozoic basement) towards the more important Rotem fault, the Dilsen fault may represent a footwall shortcut fault of the Rotem fault. In a similar manner, the Bree fault may also represent a footwall shortcut fault of the Neeroeteren fault, although the convergences of the first towards the latter is not obvious on seismic data (Fig. 3). If they do indeed represent footwall shortcut faults, the Bree and Dilsen faults would have originated during Late Cretaceous compression to accommodate inversion on the pre-existing Neeroeteren and Rotem faults. This hypothesis is supported by the fact that the base of the lower to middle Mesozoic strata shows a very similar amount of reverse vertical throw as the base of the Chalk Group along the Bree fault (Fig. 3). Nevertheless, earlier (Cimmerian) activity along the Bree and Dilsen faults cannot be excluded. Contrary to most other faults in the FFS, the Bree and Dilsen faults were not reactivated during Cenozoic extension and therefore now still have net reverse throws (Figs. 3, 10a and b).

- North of the town of Bree (for location, see Fig. 4), from the Rauw fault onwards, the Chalk Group thins in an easterly direction until it becomes absent near the Overpelt fault (Figs. 6 and 10c). East of the Overpelt fault, 
the Chalk Group is absent and reverse fault throws are unknown. The zone along which the Chalk Group thins is therefore at least $10 \mathrm{~km}$ wide. Contrary to the southern domain, the thinning of the Chalk Group is not very abrupt across major reverse faults or thrust faults in the northern domain. Instead, it takes place by small reverse displacements along faults and predominantly by upward flexuration (see flexures at the top and bottom of the Chalk Group in Figs. 6 and 10c) towards the northeast.

The transition between the southern and northern domains is located at or along the lateral extent of the GBF (Fig. 9). The Chalk Group is about $200 \mathrm{~m}$ thick in the footwall of the GBF (the CB) but absent in its hanging wall (the northern domain of the FFS), which indicates that this fault had a reverse throw of at least $200 \mathrm{~m}$ (Fig. 10d). This throw decreases in a westerly direction along the GBF (Fig. 9). Northwest of the western tip of the GBF, northwards thinning of the Chalk Group takes mainly place by upward flexuration of the preChalk Group basement (Figs. 6 and 10c).

\section{Discussion}

\subsection{Graben border activity and segmentation}

Based on stratigraphic maps extracted from the new 3D geological model of Flanders (G3Dv3 model; Deckers et al., 2019), it is shown that, in agreement with former studies (Rossa, 1986; Demyttenaere and Laga, 1988; Demyttenaere, 1989; Langenaeker, 2000), the FFS was highly active during both Late Cretaceous contraction and Cenozoic extension. Like many other faults in the region, the FFS probably developed during the middle Mesozoic early Cimmerian phase (Fig. 2). The FFS thereby enabled the structural differentiation between the RVG in its hanging wall and the relatively high $\mathrm{CB}$ in its footwall. Due to erosion during the late Cimmerian phase (Geluk et al., 1994; Fig. 2), Jurassic syn-rift strata are not preserved in the CB and only locally in the RVG (Fig. 3), which makes it difficult to reconstruct the early Cimmerian fault kinematics. However, fault-related deformation and fault-bounded preservation of Triassic and Lower Jurassic strata indicate that most faults in the FFS were active during the early Cimmerian phase.

Under Late Cretaceous compression, the RVG was inverted by reverse reactivation of the middle Mesozoic FFS. As the result, the RVG is lacking an Upper Cretaceous cover, while the neighboring CB was covered by 200-300 m of Upper Cretaceous carbonates of the Chalk Group (Figs. 3, 6, 9, and 10). The simultaneity of inversion of the RVG and subsidence of the CB in its flank is evidenced by the progressive increase in clastic sediment input in the Chalk Group in the direction of the RVG (Bless et al., 1986). The thickness maps of the Chalk Group in this study provide no indication for important Late Cretaceous fault activity in the CB (Fig. 9). Late
Cretaceous compressional strain distribution was therefore fundamentally controlled by and focused on the pre-existing FFS. The focus of strain upon the FFS might be the result of the large size it had reached during middle Mesozoic rifting, since large-sized faults have the potential to accrue displacement at the expense of smaller-sized surrounding faults (Reilly, 2017). Based on the stratigraphic thickness analyses of the Chalk Group in the CB in this study and apatite fission track analyses in boreholes in the RVG by Luijendijk et al. (2011), total Late Cretaceous reverse throws along the FFS are estimated to be in the order of $300 \mathrm{~m}$. The interpreted seismic lines (Figs. 3 and 6), map views (Fig. 9), and cross sections (Fig. 10) indicate that this reverse throw of the FFS was accommodated by reverse vertical throws along individual faults (up to $250 \mathrm{~m}$ ) as well as by upward flexuring of the pre-Chalk Group basement.

Under Cenozoic (late Oligocene to recent) extension, the middle Mesozoic faults were again reactivated (Demyttenaere, 1989). Contrary to the Late Cretaceous contraction, Cenozoic normal reactivation was not limited to the FFS, since numerous surrounding faults in the CB and RVG were also reactivated in a normal movement (Figs. 3, 7, and 10). The map of the base of the Cenozoic syn-rift strata (Fig. 7) shows that the majority of the extensional strain was again focused onto the FFS. The interpreted seismic lines (Figs. 3 and 6) and cross sections (Fig. 10) show that the FFS is characterized by a relatively high concentration of east-dipping faults with vertical offsets that exceed $150 \mathrm{~m}$. The FFS thereby forms the transition from the relatively high CB (base syn-rift strata $>-400 \mathrm{~m}$ TAW) towards the low RVG (base syn-rift strata $<-900 \mathrm{~m}$ TAW). As a result of their normal reactivation, the faults within the FFS experienced a reversal from Late Cretaceous reverse faulting towards late Cenozoic normal movements. Some faults thereby reached a net normal offset at the level of the base of the Late Cretaceous (Rotem fault; Fig. 10a), while others retain a net reverse offset at the same stratigraphic level (GBF; Fig. 10d).

However, not all of the active Late Cretaceous faults in the FFS were reactivated during the Cenozoic. The Bree and Dilsen faults (Figs. 3, 10a and b), for example, are important Late Cretaceous faults (reverse throws $>100 \mathrm{~m}$ ) in the footwalls of the Neeroeteren and Rotem faults that were not reactivated during the Cenozoic. Contrary to the other faults, the Bree and Dilsen faults might represent footwall shortcuts to accommodate Late Cretaceous inversion of the larger Neeroeteren and Rotem faults. The presence of footwall shortcut thrusts is characteristic of the early stages of inversion of extensional fault systems (McClay and Buchanan, 1992). The lack of Cenozoic reactivation of the Bree and Dilsen faults, contrary to the surrounding faults of the FFS, may relate to the Late Cretaceous origin as thrust faults of the former two compared to the middle Mesozoic origin as normal faults of the last ones. The middle Mesozoic major normal faults (Neeroeteren and Rotem), rather than their footwall shortcut thrust faults (Bree and Dilsen), thus appear to 
have been more preferable sites for the accommodation of the Cenozoic extension strain.

Maps of the Upper Cretaceous and Cenozoic stratigraphic distributions and thicknesses (Figs. 7 and 9) indicate that the geometry of the FFS shows major lateral changes into distinct structural domains. We identified two of those structural domains in the Belgian sector of the FFS, which existed during both Late Cretaceous contraction and Cenozoic extension:

- In the southern domain, the FFS is characterized by a narrow $(<2 \mathrm{~km})$ border fault zone that is dominated by localized faulting. During the Late Cretaceous compression, this domain was dominated by several faults with reverse throws of over $200 \mathrm{~m}$ and during Cenozoic extension by the large Neeroeteren fault with a normal throw of almost $600 \mathrm{~m}$.

- In the northern domain, the FFS is characterized by a wide (average $>10 \mathrm{~km}$ ) border fault zone that is dominated by distributed faulting. During the Late Cretaceous compression this domain was characterized by upward flexuring of the pre-Chalk Group basement and faults with generally small reverse throws and during Cenozoic extension by downwards tilting of the pre-rift strata and faults with total throws of less than $250 \mathrm{~m}$.

The northern and southern domains thus show persistent distributed and localized strain, respectively, during phases of both contraction (Late Cretaceous) and extension (Cenozoic). Faults with the largest Late Cretaceous reverse throw therefore also had the largest Cenozoic normal throw. Mora et al. (2009) showed that for the Eastern Cordillera of Colombia the same is true for faults that have been reactivated in the opposite way (i.e., faults with the largest normal throws also showed the largest reverse throw during reactivation). The width of deformation, the degree of shortening, the spatial development of structures, and the focus of ongoing tectonic activity seems to be fundamentally influenced by the inherited structures (Mora et al., 2006). The similarity of the geometry of the different domains of the FFS during both Late Cretaceous inversion and Cenozoic extension shows that inherited structures also controlled the evolution of the border zone of the RVG. This emphasizes the importance of preexisting structural domains on tectonic deformation during both inversion and extension, besides more obvious factors such as the fault strikes with respect to the stress-field orientations. Indeed, under Late Cretaceous contraction and Cenozoic extension, strain distribution remained similar in both structural domains of the FFS, while maximum horizontal stress was estimated to be N-S to NNW-SSE for the first phase (de Jager, 2003) and NNE-SSW to NW-SE for the latter phase (Michon et al., 2003; Michon and Van Balen, 2005).

\subsection{Possible cause for segmentation}

The abovementioned geometrical changes in the FFS had no influence on its total Cenozoic vertical throw, which remains in the order of $600 \mathrm{~m}$ across both domains (Figs. 7 and 10e). They also seem to have had little effect upon the thicknesses of the Upper Cretaceous Chalk Group, which remains in the order of $250-300 \mathrm{~m}$ across the footwall of both domains of the FFS (Fig. 9). This shows that a similar amount of strain (extensional and compressional) was distributed differently between the southern and northern domains of the FFS, namely localized in the first and distributed in the latter. Localized and distributed regimes of faulting are known to have occurred within one fault system (Soliva and Schultz, 2008; Nixon et al., 2014), similar to the FFS in this study. Differences between these regimes are often attributed to the maturity of the fault systems (Nixon et al., 2014): highly mature systems are linked and have localized strain, whereas younger (less mature) faults are less linked and more diffuse. In our study area, however, the difference in strain localization cannot be related to differences in maturity, since the FFS is a long-lived system, already active since at least the middle Mesozoic. Alternatively, such as is the case in the East African Rift system, the difference in fault localization could be attributed to the presence of magmatic intrusions (Ebinger and Casey, 2001; Kendall et al., 2005; Wright et al., 2006) or oblique pre-existing shear zones (Katumwehe et al., 2015; Dawson et al., 2018). The RVG is, however, considered amagmatic during the Late Cretaceous and Cenozoic, and pre-existing shear zones were up to very recently not known at the junction between the two domains. The nearest known shear zone is the Gruitrode Lineament, a latest Carboniferous dextral transpressional flexure zone (Bouckaert and Dusar, 1987) that runs NE-SW in the CB west of the Bree Uplift (Langenaeker, 2000; Figs. 3 and 5). In a recent $3 \mathrm{D}$ modeling campaign of the latest Carboniferous strata, the strike of the Gruitrode Lineament was revised into a NNE-SSW orientation (Rombaut et al., 2021; for location see Fig. 5). As a result, the new trace of the Gruitrode Lineament cuts the FFS at the junction between the southern and northern domain of this study. The Gruitrode Lineament does not seem to continue east of the FFS or in the RVG (Rombaut et al., 2021; Fig. 5). This shows that some of the faults in the FFS (at least the Neeroeteren and Bocholt faults) influenced activity along the Gruitrode Lineament. The Neeroeteren and Bocholt faults are part of the population of NW-SE-striking faults, some of which were already active early in the Carboniferous (Muchez and Langenaeker, 1993), and could therefore indeed have played an important role during the latest Carboniferous formation of the Gruitrode Lineament. During middle Mesozoic rifting, the same NW-SE-striking faults were reactivated again and became, in the case of the Neeroeteren and Bocholt faults, part of the larger FFS in the border of the RVG. The Gruitrode Lineament on the other hand was not reactivated after the 
Paleozoic, as evidenced by the lack of deformation in its overburden (Bouckaert and Dusar, 1987). Because of its position at the boundary between the different domains, the Gruitrode Lineament did, however, play an important role in the segmentation of the FFS into the abovementioned two domains. Also further west in the $\mathrm{CB}$, the middle Mesozoic fault pattern is known to have been influenced by another predominantly NNE-SSW-striking (Deckers et al., 2019) latest Carboniferous transpressional flexure zone, called the Donderslag Lineament, that itself was not reactivated during the Mesozoic (Dusar and Langenaeker, 1992; Langenaeker, 2000). We therefore regard the presence of oblique Carboniferous strike-slip fault systems as a likely cause for changes in strain distribution between the middle Mesozoic fault populations, such as the FFS. These differences in strain distributions persisted when the fault populations were reactivated during the Late Cretaceous and Cenozoic tectonic phases.

\subsection{The role of non-collinear faults in accommodating segmentation}

The southern and northern structural domains of the FFS as identified in this study are both dominated by NWSE-striking faults. The boundary between these domains is sharp, as it coincides with the oblique (non-collinear), WNW-ESE-striking GBF. The GBF transitions the FFS from localized faulting in a narrow southern border zone to distributed faulting in a wide northern border zone. The transition from localized to distributed faulting is not abrupt but stepwise as strain is redistributed along the GBF from the Neeroeteren fault at its eastern tip towards connecting faults (of the northern structural domain) further west:

- As the Neeroeteren fault branches into the GBF and Bocholt faults, the total throw of the Neeroeteren Fault is divided between these two faults (Figs. 7 and 8).

- At the bifurcation between the GBF and Reppel faults, the total throw of the GBF also decreases by an amount equal to the throw of the Reppel Fault (Figs. 7 and 8).

- At the location where the GBF dies out, no more large displacement faults were observed in the northern domain (Fig. 7).

The GBF thereby causes a major left-stepping pattern in the FFS. North and south of the study area, other major WNWESE-striking faults, such as the Veldhoven and Lövenicher faults (see Fig. 1 for their locations), are associated with similar left-stepping patterns and even larger geometrical changes in the border fault systems of the Cenozoic Roer Valley rift system. At both of their lateral tips, the Veldhoven and Lövenicher-Kast faults connect to large (total syn-rift throws $>200 \mathrm{~m}$ ) NW-SE-striking faults (Klett et al., 2002; Vernes et al., 2018). The GBF is only known to be delimited along its eastern fault tip by the major NW-SE-striking
Neeroeteren fault, while due to lack of data coverage, the geometry of its western fault tip remains uncertain. However, given the limited total syn-rift throw $(100 \mathrm{~m})$ at its westernmost seismically covered section, a connection with a major NW-SE fault here seems unlikely. This is consistent with the smaller maximum vertical Cenozoic throw along the GBF $(<250 \mathrm{~m})$ compared to the Veldhoven and Lövenicher faults (locally $>500 \mathrm{~m}$ ). Geological maps of the thickness of the Chalk Group in the Netherlands (Duin et al., 2006) illustrate that the Veldhoven fault, just like the GBF, was also already of major importance during the Late Cretaceous inversion of the RVG. The non-collinear faults therefore played an important role in accommodating long-lived strain redistribution along the RVG border fault systems, under phases of both compression and extension.

\section{Conclusions}

The Roer Valley graben is bounded by large, NW-SEstriking border fault systems that probably developed during the middle Mesozoic. During phases of Late Cretaceous contraction and Cenozoic extension, these border fault systems were reactivated. The western border fault system, i.e., the Feldbiss fault system (FFS), is located in northeastern Belgium. Based on careful evaluation of the new geological 3D model of Flanders (northern Belgium), this study shows the presence of two structural domains in the FFS with distinctly different strain distributions during both Late Cretaceous compression and Cenozoic extension:

- The southern domain is characterized by narrow ( $<3 \mathrm{~km}$ wide) localized faulting, with Late Cretaceous reverse throws of over $200 \mathrm{~m}$ and Cenozoic normal throw of almost $600 \mathrm{~m}$.

- The northern domain is characterized by broad ( $>10 \mathrm{~km}$ wide) distributed faulting and tilting of the pre-inversion and pre-rift strata during these subsequent phases.

The total amount of normal and reverse throws in the two domains of the FFS was estimated to be similar during both tectonic phases. This shows that each domain accommodated a similar amount of deformation but distributed it differently, whether during inversion or extension. This emphasizes that pre-existing structural domains in fault systems can have a strong influence on the later fault reactivation.

Between both structural domains of the FFS, a major NNE-SSW-striking latest Carboniferous transpressional structure was recently mapped, called the Gruitrode Lineament. As was illustrated in the East African Rift system, pre-existing lineaments can be the cause of segmentation and redistribution of strain in rift border fault systems. Further southwest and parallel to the Gruitrode Lineament, another latest Carboniferous transpressional structure (Donderslag Lineament) is known to coincide with an important 
change in fault patterns. The oblique Carboniferous strikeslip fault systems are therefore regarded as a likely cause for the changes in strain distribution within the middle Mesozoic FFS, which persisted as this system was reactivated during the Late Cretaceous and Cenozoic tectonic phases.

The faults in the two structural domains of the FFS strike dominantly NW-SE, but the change in geometry between them takes place across the oblique WNW-ESE-striking Grote Brogel fault. This fault thereby progressively widened the FFS in a northerly direction, redistributing localized strain from predominantly a single fault in the southern domain into several smaller faults in the northern domain. Also in other parts of the Roer Valley graben, WNW-ESE-striking faults are associated with major geometrical changes (leftstepping patterns) in its border fault system.

Data availability. The depth and thickness maps and fault traces can be downloaded from https://www.dov.vlaanderen.be.

Author contributions. JD and BR came up with the idea of the paper. JD wrote the paper and made the initial figures apart from Fig. 1 and those of the seismic sections by support of KvB (see acknowledgements). BR did the first review of the paper and created the figures of the seismic sections. $\mathrm{KV}$ and $\mathrm{KV}$ did a subsequent review and made numerous suggestions for improvements of the text and structure. KV created Fig. 1.

Competing interests. The authors declare that they have no conflict of interest.

Special issue statement. This article is part of the special issue "Inversion tectonics - 30 years later". It is a result of the EGU General Assembly 2019, Vienna, Austria, 7-12 April 2019.

Acknowledgements. We gratefully acknowledge financial support from the Bureau for Environment and Spatial Development - Flanders. We would like to thank Katleen van Baelen for her work on the figures. We thank Alexander Malz, Christopher Jackson, and Jonas Kley for their helpful reviews and recommendations that led to considerable improvements of the paper.

Review statement. This paper was edited by Piotr Krzywiec and reviewed by Christopher Jackson, Alexander Malz, and Jonas Kley.

\section{References}

Agentschap Informatie Vlaanderen: Digital Terrain Model Flanders II, Resolution $100 \mathrm{~m}$, Flemish Government, availabe at: https:// overheid.vlaanderen.be/dhm-dhmv-ii-standaard-producten, last access: 1 December 2018.

Beerten, K., Vandenberghe, N., Gullentops, F., and Paulissen, E. Toelichting bij de Quartairgeologische Kaart, Maaseik, Vlaamse overheid, dienst Natuurlijke Rijkdommen, kaartblad 10-18, 2005.

Beerten, K., De Craen, M., and Wouters, L.: Patterns and estimates of post-Rupelian erosion in the Campine area, north-eastern Belgium, Phys. Chem. Earth, 64, 12-20, 2013.

Bless, M. J. M., Felder, P. J., and Meessen, J. P.: Late Cretaceous sea level rise and inversion: their influence on the depositional environment between Aachen and Antwerp, Annales de la Société géologique de Belgique 109, 333-355, 1986.

Bouckaert, J., and Dusar, M.: Arguments géophysiques pour une tectonique cassante en Campine (Belgique), active au Paléozoique supérieur et réactive depuis le Jurassique supérieur, Annales de la Société Géologique du Nord, 106, 201-208, 1987.

Broothaers, M., Deckers, J., Lagrou, D., and Matthijs, J.: 3Dlagenmodel van de Tertiaire afzettingen in de Roerdalslenk in Vlaanderen, VITO-rapport 2012/SCT/R/191, VITO, Mol (Belgium), 58 pp., 2012.

Camelbeeck, T. and Meghraoui, M.: Large earthquakes in northern Europe more likely than once thought, Eos. Trans. AGU, 77, 405-409, 1996.

Dawson, S. M., Laó-Dávila, D. A., Atekwana, E. A., and Abdelsalam, M. G.: The influence of the Precambrian Mughese Shear Zone structures on strain accommodation in the northern Malawi Rift, Tectonophysics, 722, 53-68, 2018.

Deckers, J.: The Late Oligocene to Early Miocene early evolution of rifting in the south-western part of the Roer Valley Graben, Int. J. Earth Sci., 105, 1233-1243, 2016.

Deckers, J. and Van der Voet, E.: A review on the structural styles of deformation during Late Cretaceous and Paleocene tectonic phases in the southern North Sea area, J. Geodyn., 115, 1-9, 2018.

Deckers, J., Vernes, R., Dabekaussen, W., Den Dulk, M., Doornenbal, H., Dusar, M., Matthijs, J., Menkovic, A., Reindersma, R., Walstra, J., Westerhoff, W., and Witmans, N.: Geologisch en hydrogeologisch 3D model van het Cenozoïcum van de Roerdalslenk in Zuidoost-Nederland en Vlaanderen (H3ORoerdalslenk), VITO-rapport, 2014/ETE/R/1, VITO, Mol (Belgium), 200 pp., 2014.

Deckers, J., Van Noten, K., Schiltz, M., Lecocq, T., and Vanneste, K.: Integrated study on the topographic and shallow subsurface expression of the Grote Brogel Fault at the boundary of the Roer Valley Graben, Belgium, Tectonophysics, 722, 486-506, 2018.

Deckers, J., De Koninck, R., Bos, S., Broothaers, M., Dirix, K. Hambsch, L., Lagrou, D., Lanckacker, T., Matthijs, J., Rombaut, B., Van Baelen, K., and Van Haren, T.: Geologisch (G3D) en hydrogeologisch (H3D) 3D-lagenmodel van Vlaanderen versie 3, VITO-rapport 2018/RMA/R/1569, Vlaams Planbureau voor Omgeving, departement Omgeving en de Vlaamse Milieumaatschappij, Brussels, Belgium, 331 pp., 2019. 
De Jager, J.: Inverted basins in the Netherlands, similarities and differences, Neth. J. Geosci., 82, 355-366, 2003.

Demyttenaere, R.: The post-Paleozoic geological history of northeastern Belgium, Letteren en Schone Kunsten van België, 51, 51-81, 1989.

Demyttenaere, R. and Laga, P. G.: Breuken - en isohypsenkaarten van het Belgisch gedeelte van de Roerdalslenk, eerste resultaten van een seismisch onderzoek in het gebied Poppel-LommelMaaseik, Ministerie van Economische Zaken, Administratie der Mijnen, België, Geologische Dienst van België, Brussels, Beligum, 22 pp., 1988.

DOV: Flanders Soil and Subsoil Database (Databank Ondergrond Vlaanderen)availabe at: https://www.dov.vlaanderen.be, last access: 1 December 2018.

Duin, E. J. T., Doornenbal, J. C., Rijkers, R. H. B., Verbeek, J. W., and Wong, T. E.: Subsurface structure of the Netherlands - results of recent onshore and offshore mapping, Neth. J. Geosci., 85, 245-276, 2006.

Dusar, M. and Langenaeker, V.: De oostrand van het Massief van Brabant met beschrijving van de geologische verkenningsboring te Martenslinde, Geological Survey of Belgium Professional Paper, 255, 22 pp., 1992.

Ebinger, C. and Casey, M.: Continental breakup in magmatic provinces: an Ethiopian example, Geology, 29, 527-530, 2001.

Everaerts, M. and De Vos, W.: Gravity acquisition in Belgium and the resulting Bouguer anomaly map, Mem. Geol. Surv. Belgium, 58, 64 pp., 2012.

Geluk, M. C.: The Cenozoic Roer Valley Graben, Southern Netherlands, Meded Rijks Geol. Dienst., 44, 65-72, 1990.

Geluk, M. C., Duin, E. J., Dusar, M., Rijkers, R. H., van den Berg, M. W., and van Rooijen, P.: Stratigraphy and tectonics of the Roer Valley Graben, Geol. Mijnb., 73, 129-141, 1994.

Katumwehe, A. B., Abdelsalam, M. G., and Atekwana, E. A.: The role of pre-existing Precambrian structures in rift evolution: the Albertine and Rhino grabens, Uganda, Tectonophysics, 646, 117-129, 2015.

Kendall, J. M., Stuart, G. W., Ebinger, C. J., Bastow, I. D., and Keir, D.: Magma-assisted rifting in Ethiopia, Nature, 433, 146-148, 2005.

Klett, M., Eichhorst, F., and Schäfer, A.: Facies interpretation from well-logs applied to the Tertiary Lower Rhine Basin fill, Neth. J. Geosci., 81, 167-176, 2002.

Kley, J. and Voigt, T.: Late Cretaceous intraplate thrusting in central Europe: effect of Africa-Iberia-Europe convergence, not Alpine collision, Geology, 36, 839-842, 2008.

Langenaeker, V.: The Campine Basin: stratigraphy, structural geology, coalification and hydrocarbon potential for the Devonian to Jurassic, Aardkundige Mededelingen, 10, 1-142, 2000.

Luijendijk, E., Van Balen, R. T., Ter Voorde, M., and Andriessen, P. A. M.: Reconstructing the Late Cretaceous inversion of the Roer Valley Graben (southern Netherlands) using a new model that integrates burial and provenance history with fission track thermochronology, J. Geophys. Res., 116, B06402, https://doi.org/10.1029/2010JB008071, 2011.

Matthijs, J., Lanckacker, T., De Koninck, R., Deckers, J., Lagrou, D., and Broothaers, M.: Geologisch 3D lagenmodel van Vlaanderen en het Brussels Hoofdstedelijk Gewest, versie 2, G3Dv2, VITO Departement Leefmilieu, Natuur en Energie, Afdeling Land en Bodembescherming, Ondergrond, Natuurlijke Rijk- dommen, VITO-rapport 2013/R/ETE/43, VITO, Mol (Belgium), 2013.

McClay, K. R. and Buchanan, P. G.: Thrust faults in inverted extensional basins in: Thrust Tectonics, edited by: McClay, K. R., London, Chapman \& Hall, 93-104, 1992.

Meyus, Y., Cools, J., Adyns, D., Zeleke, S. Y., Woldeamlak, S. T., Batelaan, O., and De Smedt, F.: Hydrogeologische detailstudie van de ondergrond in Vlaanderen, Eindrapport, Ministerie van de Vlaamse Gemeenschap, Administratie Milieu-, Natuur-, Landen Waterbeheer, Afdeling Water, Brussel, 107 pp., 2005.

Michon, L. and Van Balen, R. T.: Characterization and quantification of active faulting in the Roer valley rift system based on high precision digital elevation models, Quaternary Sci. Rev., 24, 457-474, 2005.

Michon, L., Van Balen, R. T., Merle, O., and Pagnier, H.: The Cenozoic evolution of the Roer Valley Rift system integrated at a European scale, Tectonophysics, 367, 101-126, 2003.

Mora, A., Parra, M., Strecker, M. R., Kammer, A., Dimaté, C., and Rodriguez, F.: Cenozoic contractional reactivation of Mesozoic extensional structures in the Eastern Cordillera of Colombia, Tectonics, 25, TC2010, https://doi.org/10.1029/2005TC001854, 2006.

Mora, A., Gaona, T., Kley, J., Montoya, D., Parra, M., Quiroz, L. I., Reyes, G., and Strecker, M. R.: The role of inherited extensional fault segmentation and linkage in contractional orogenesis: a reconstruction of lower cretaceous inverted rift basins in the eastern cordillera of Colombia, Basin Res., 21, 111-137, 2009.

Muchez, P. and Langenaeker, V.: Middle Devonian to Dinantian sedimentation in the Campine Basin (northern Belgium): its relation to Variscan tectonism, in: Tectonic Controls and Signature in Sedimentary Successions, edited by: Frostick, L. E. and Steel, R. J., Special Publication of the International Association of Sedimentologists, 171-181, 1993.

Nixon, C. W., Bull, J. M., and Sanderson, D. J.: Localized vs distributed deformation associated with the linkage history of an active normal fault, Whakatane Graben, New Zealand, J. Struct. Geol., 69, 266-280, 2014.

Paulissen, E.: Quaternary morphotectonics in the Belgian part of the Roer Graben, Aardkundige Mededelingen, 8, 131-134, 1997.

Reilly, C., Nicol, A., and Walsh, J.: Importance of pre-existing fault size for the evolution of an inverted fault system, Geol. Soc. Spec. Publ., 439, 447-463, 2017.

Rombaut, B., Deckers, J., Katrijn, D., and Van Baelen, K.: Nieuwe geologische 3D-modellen van en inzichten over het boven Westfaliaan in Vlaanderen, VITO-rapport 2020/RMA/R/2142, VITO, Mol (Belgium), in preparation, 2021.

Rossa, H. G.: Upper Cretaceous and Tertiary inversion tectonics in the western part of the Rhenish-Westphalian coal district (FRG) and in the Campine area (N Belgium), Annales de la Société géologique de Belgique, 109, 367-410, 1986.

Rosenbaum, G., Lister, G. S., and Duboz, C.: Relative motions of Africa, Iberia and Europe during Alpine orogeny, Tectonophysics, 359, 117-129, 2002.

Rypens, J., Sintubin, M., and Dusar, M.: Geometry and kinematics of the southwestern border fault system of the Roer Valley Graben (NE Belgium), KU Leuven and Belgische Geologische Dienst, Belgium, 86 pp., 2004. 
Seismic catalogue of the Royal Observatory of Belgium, available at: http://seismologie.be/en/seismology/seismicity-in-belgium, last access: 1 December 2019.

Sels, O., Claes, S., and Gullentops, F.: Toelichtingen bij de Geologische kaart van België Vlaams Gewest 1:50.000, Kaartblad 18-10 Maaseik + Beverbeek, Belgische Geologische Dienst en Ministerie van de Vlaamse Gemeenschap, Afdeling Natuurlijke Rijkdommen en Energie, Brussel, Belgium, 2001.

Soliva, R. and Schultz, R. A.: Distributed and localized faulting in extensional settings: Insight from the North Ethiopian RifteAfar transition area, Tectonics, 27, TC2003, 2008.

Vanneste, K., Camelbeeck, T., and Verbeeck, K.: A model of composite seismic sources for the Lower Rhine Graben, Northwest Europe. Bull. Seismol. Soc. Am., 103, 984-1007, 2013.

Verbeeck, K., Wouters, L., Vanneste, K., Camelbeeck, T., Vandenberghe, D., Beerten, K., Rogiers, B., Schiltz, M., Burow, C., Mees, F., De Grave, J., and Vandenberghe, N.: Episodic activity of a dormant fault in tectonically stable Europe: The Rauw fault (NE Belgium), Tectonophysics, 699, 146-163, https://doi.org/10.1016/j.tecto.2017.01.023, 2017.

Verbeurgt, J., Camp, M., Van Stal, C., Camelbeeck, T., Sloover, L., De Poppe, H., Declercq, P. Y., Voet, P., Constales, D., Troch, P., De Maeyer, P., and De Wulf, A.: The gravity database for Belgium, Geosci. Data J., 6, 116-125, 2019.
Vernes, R. W., Deckers, J., Bakker, M. A. J., Bogemans, F., De Ceukelaire, M., Doornenbal, J. C., den Dulk, M., Dusar, M., Van Haren, T. F. M., Heyvaert, V. M. A., Kiden, P., Kruisselbrink, A F., Lanckacker, T., Menkovic, A., Meyvis, B., Munsterman, D. K., Reindersma, R., ten Veen, J. H., van de Ven, T. J. M., Walstra, J., and Witmans, N.: Geologisch en hydrogeologisch 3D model van het Cenozoïcum van de Belgisch-Nederlandse grensstreek van Midden-Brabant/De Kempen $\left(\mathrm{H}_{3} \mathrm{O}-\right.$ De Kempen), VITO, TNO-Geologische Dienst Nederland en de Belgische Geologische Dienst, Vlaams Planbureau voor Omgeving, Vlaamse Milieumaatschappij, TNO, Geologische Dienst Nederland, Nederlandse Provincie Noord-Brabant, Brabant Water, Programmabureau KRW/DHZ Maasregio, TNO: Utrecht, VITO: Mol, Belgische Geologische Diest: Brussels, 109 pp., 2018.

Worum, G., Michon, L., van Balen, R. T., van Wees, J.-D., Cloetingh, S., and Pagnier, H.: Pre-Neogene controls on present-day fault activity in the West Netherlands Basin and Roer Valley Rift System (southern Netherlands): role of variations in fault orientation in a uniform low-stress regime, Quaternary Sci. Rev., 24, 473-488, 2005.

Wright, T. J., Ebinger, C., Biggs, J., Ayele, A., Yirgu, G., Keir, D., and Stork, A.: Magmamaintained rift segmentation at continental rupture in the 2005 Afar dyking episode, Nature, 442, 291-294, 2006.

Ziegler, P. A.: Evolution of the Artic North Atlantic and the western Tethys, Am. Assoc. Pet. Geol. Mem., 43, 1-198, 1988. 